\title{
Structural Properties and Isotopic Abundance Ratio Analysis of Magnesium Gluconate Treated with the Energy of Consciousness Using LC-MS and NMR Spectroscopy
}

\author{
Mahendra Kumar Trivedi ${ }^{1}$, Alice Branton ${ }^{1}$, Dahryn Trivedi ${ }^{1}$, Gopal Nayak ${ }^{1}$, \\ Ariadne Esmene Afaganis ${ }^{1}$, Barbara Marie Bader ${ }^{1}$, Brian A. Weekes ${ }^{1}$, Daphne Luisa Dumas ${ }^{1}$, \\ Denise Marie Fiedler ${ }^{1}$, Dennille Mellesia Smith ${ }^{1}$, Desi Pano ${ }^{1}$, Donna Felice Galla ${ }^{1}$, \\ Donna Maria Alija ${ }^{1}$, Elaine Barbara Mullins ${ }^{1}$, Elaine M. Scorza ${ }^{1}$, Ellia O'Donnell, \\ Fabio Massimo Paciucci ${ }^{1}$, Frances Goodman Warlick ${ }^{1}$, Haddon Norman Salt ${ }^{1}$, Inthirani Arul ${ }^{1}$, \\ Jacqueline Y. Andrews ${ }^{1}$, James Jay McLeran ${ }^{1}$, James Stephen Burnett ${ }^{1}$, Jean Caroline White ${ }^{1}$, \\ Parthasarathi Panda ${ }^{2}$, Kalyan Kumar Sethi², Snehasis Jana ${ }^{2, *}$ \\ ${ }^{1}$ Trivedi Global, Inc., Henderson, Nevada, USA \\ ${ }^{2}$ Trivedi Science Research Laboratory Pvt. Ltd., Bhopal, Madhya Pradesh, India
}

Email address:

publication@trivedieffect.com (S. Jana)

*Corresponding author

To cite this article:

Mahendra Kumar Trivedi, Alice Branton, Dahryn Trivedi, Gopal Nayak, Ariadne Esmene Afaganis, Barbara Marie Bader, Brian A. Weekes, Daphne Luisa Dumas, Denise Marie Fiedler, Dennille Mellesia Smith, Desi Pano, Donna Felice Galla, Donna Maria Alija, Elaine Barbara Mullins, Elaine M. Scorza, Ellia O'Donnell, Fabio Massimo Paciucci, Frances Goodman Warlick, Haddon Norman Salt, Inthirani Arul, Jacqueline Y. Andrews, James Jay McLeran, James Stephen Burnett, Jean Caroline White, Parthasarathi Panda, Kalyan Kumar Sethi, Snehasis Jana. Structural Properties and Isotopic Abundance Ratio Analysis of Magnesium Gluconate Treated with the Energy of Consciousness Using LC-MS and NMR Spectroscopy. International Journal of Applied Agricultural Sciences.

Vol. 3, No. 2, 2017, pp. 37-46. doi: 10.11648/j.ijaas.20170302.12

Received: February 6, 2017; Accepted: February 27, 2017; Published: March 20, 2017

\begin{abstract}
The present study was aimed to evaluate the impact of The Trivedi Effect ${ }^{\circledR}$ - Energy of Consciousness Healing Treatment (Biofield Energy Healing Treatment) on magnesium gluconate for the change in the structural properties and isotopic abundance ratio $\left(\mathrm{P}_{\mathrm{M}+1} / \mathrm{P}_{\mathrm{M}}\right.$ and $\left.\mathrm{P}_{\mathrm{M}+2} / \mathrm{P}_{\mathrm{M}}\right)$ using LC-MS and NMR spectroscopy. Magnesium gluconate was divided into two parts - one part was control, and another part was treated with The Trivedi Effect ${ }^{\mathbb{B}}$ - Biofield Energy Healing Treatment remotely by twenty renowned Biofield Energy Healers and defined as The Trivedi Effect ${ }^{\mathbb{B}}$ treated sample. The LC-MS analysis of both the control and treated samples revealed the presence of the mass of the protonated magnesium gluconate at $\mathrm{m} / \mathrm{z} 415$ at the retention time of $1.52 \mathrm{~min}$ with almost similar fragmentation pattern. The relative peak intensities of the fragment ions of the treated sample were significantly altered compared with the control sample. The proton and carbon signals for $\mathrm{CH}, \mathrm{CH}_{2}$ and $\mathrm{CO}$ groups in the proton and carbon NMR spectra were found almost similar for the control and the treated samples. The isotopic abundance ratio analysis revealed that the isotopic abundance ratios of $\mathrm{P}_{\mathrm{M}+1} / \mathrm{P}_{\mathrm{M}}\left({ }^{2} \mathrm{H} /{ }^{1} \mathrm{H}\right.$ or ${ }^{13} \mathrm{C} /{ }^{12} \mathrm{C}$ or ${ }^{17} \mathrm{O} /{ }^{16} \mathrm{O}$ or $\left.{ }^{25} \mathrm{Mg} /{ }^{24} \mathrm{Mg}\right)$ and $\mathrm{P}_{\mathrm{M}+2} / \mathrm{P}_{\mathrm{M}}\left({ }^{18} \mathrm{O} /{ }^{16} \mathrm{O}\right.$ or $\left.{ }^{26} \mathrm{Mg} /{ }^{24} \mathrm{Mg}\right)$ were significantly decreased in the treated sample by $35.97 \%$ and $66.77 \%$, respectively compared with the control sample. Briefly, ${ }^{13} \mathrm{C},{ }^{2} \mathrm{H},{ }^{17} \mathrm{O}$, and ${ }^{25} \mathrm{Mg}$ contributions from $\left(\mathrm{C}_{12} \mathrm{H}_{23} \mathrm{MgO}_{14}\right)^{+}$to $\mathrm{m} / z$ 416; ${ }^{18} \mathrm{O}$ and ${ }^{26} \mathrm{Mg}$ contributions from $\left(\mathrm{C}_{12} \mathrm{H}_{23} \mathrm{MgO}_{14}\right)^{+}$to $\mathrm{m} / \mathrm{z} 417$ in the treated sample were significantly reduced compared with the control sample. Thus, The Trivedi $\mathrm{Effect}^{\mathbb{B}}$ treated magnesium gluconate could be valuable for designing better pharmaceutical and/or nutraceutical formulations through its changed physicochemical and thermal properties, which might be providing better therapeutic response against various diseases such as diabetes mellitus, allergy, aging, inflammatory diseases, immunological disorders, and other chronic infections. The Trivedi Effect ${ }^{\circledR}$ Treated magnesium gluconate might be supportive to design the novel potent enzyme inhibitors using its kinetic isotope effects.
\end{abstract}


Keywords: Consciousness Energy Healing Treatment, The Trivedi Effect ${ }^{\circledR}$, Biofield Energy Healers, Magnesium Gluconate, LC-MS, Isotopic Abundance Ratio, Kinetic Isotope Effects, NMR

\section{Introduction}

Magnesium ion $\left(\mathrm{Mg}^{2+}\right)$ is an essential nutrient as a structural constituent of bone, regulator of more than 300 enzymes, cofactor for synthesis of DNA, RNA, reproduction and protein, vital coherent controller of glycolysis and the Krebs cycle [1-3]. Magnesium gluconate, the organometallic salt of magnesium with gluconic acid, is useful for the prevention and treatment of many diseases such as cardiovascular diseases, diabetes mellitus, allergy, inflammatory diseases, immunological disorders, Alzheimer's disease, asthma, pre-eclampsia, eclampsia, cancer, oxidative stress induced ischemia/reperfusion injury, etc. [4-9]. It can be used as neuroprotective [10], an oral tocolytic agent [11], and also in a skin-tightening cosmetic composition [12]. Magnesium gluconate displayed the highest bioavailability and most physiologically acceptable salt among other magnesium salts like chloride, sulfate, carbonate, acetate, citrate, lactate, aspartate, etc. [8, 13]. Therefore, magnesium gluconate was considered as one of the components in a novel proprietary herbomineral formulation for the source of magnesium ion. This herbomineral formulation which is designed as nutraceutical supplement can be used for the prevention and treatment of various human diseases.

Since ancient times, many different cultures, religions and systems of belief have recognized a living force that preserves and inhabits every living organism. This force is the source of 'life' and has been called various names, such as prana by the Hindus, qi or chi by the Chinese, and ki by the Japanese. This is believed to co-relate with the soul, spirit and mind. This hypothetical vital force has been scientifically evaluated and is now considered the Bioenergetics Field. The Biofield Energy is a dynamic electromagnetic field surrounding the human body, resulting from the continuous emission of low-level light, heat, and acoustical energy from the body. Biofield Energy is infinite, para-dimensional and can freely flow between the human and environment [14, 15]. F Sances et al. reported that Biofield Energy can be transmitted into any living organism(s) or nonliving object(s) around the globe with scientifically measurable effect through the intentional mental energies by specific energy healers [16]. The object or recipient always receives the energy from the ionosphere of the earth, the "universal energy field" and responds in a useful way. This process is known as The Trivedi Effect ${ }^{\mathbb{R}}$ - Biofield Energy Healing Treatment [17]. Biofield (Putative Energy Field) based Energy Therapies are used worldwide to promote health and healing. The National Center of Complementary and Integrative Health (NCCIH) has recognized and accepted Biofield Energy Healing as a Complementary and Alternative Medicine (CAM) health care approach in addition to other therapies, medicines and practices such as natural products, deep breathing, yoga, Tai Chi, Qi Gong, chiropractic/osteopathic manipulation, meditation, massage, special diets, homeopathy, progressive relaxation, guided imagery, acupressure, acupuncture, relaxation techniques, hypnotherapy, healing touch, movement therapy, pilates, rolfing structural integration, mindfulness, Ayurvedic medicine, traditional Chinese herbs and medicines, naturopathy, essential oils, aromatherapy, Reiki, cranial sacral therapy and applied prayer (as is common in all religions, like Christianity, Hinduism, Buddhism and Judaism) [18]. Biofield Energy Treatment (The Trivedi Effect $^{\circledR}$ ) has been drawn attention more in the recent times for its scientifically measurable capability to transform the characteristic properties of a wide varieties living and nonliving substances such as animals [19], cancer cells [20], microbes [21, 22], plants [23, 24], medium [25, 26], materials [27, 28], pharmaceuticals [29, 30], nutraceuticals $[31,32]$, organic compounds [33-35]. The scientific study indicated that Biofield Energy Healing Treatment (The Trivedi Effect ${ }^{\circledR}$ ) might be an alternate method for increasing or decreasing the natural isotopic abundance ratio of the substances [36-39]. The stable isotope ratio analysis has the wide applications in several scientific fields for understanding the isotope effects resulting from the variation of the isotopic composition of the molecule [40, 41]. Conventional mass spectrometry (MS) techniques such as liquid chromatography-mass spectrometry (LC-MS), gas chromatography-mass spectrometry (GC-MS) are widely used for isotope ratio analysis with sufficient precision [42]. Hence, LC-MS and NMR (Nuclear Magnetic Resonance) methods were applied in this study to characterize the structural properties of the Biofield Energy Treated and untreated magnesium gluconate qualitatively for the purpose of the pharmaceutical and nutraceutical industrial applications. Consequently, LC-MS based isotopic abundance ratio $\left(\mathrm{P}_{\mathrm{M}+1} / \mathrm{P}_{\mathrm{M}}\right.$ and $\left.\mathrm{P}_{\mathrm{M}+2} / \mathrm{P}_{\mathrm{M}}\right)$ analysis in both the Biofield Energy Treated and untreated samples was designed to explore the effect of The Trivedi Effect ${ }^{\circledR}$ - Biofield Energy Healing on the isotopic abundance ratio in magnesium gluconate.

\section{Materials and Methods}

\subsection{Chemicals and Reagents}

Magnesium gluconate hydrate was purchased from Tokyo Chemical Industry Co., Ltd. (TCI), Japan. All other chemicals used in the experiment were of analytical grade available in India.

\subsection{Energy of Consciousness Treatment Strategies}

Magnesium gluconate was one of the components of the 
new proprietary herbomineral formulation, which was developed by our research team and was used per se as the test compound for the current study. The test compound was divided into two parts, one part of the test compound did not receive any sort of treatment and was defined as the untreated or control magnesium gluconate sample. The second part of the test compound, which was denoted as The Trivedi Effect ${ }^{\circledR}$ Treated sample, was treated with The Trivedi Effect ${ }^{\circledR}$ Energy of Consciousness Healing Treatment (Biofield Energy Healing Treatment) by a group of twenty renowned Biofield Energy Healers remotely. Thus, Biofield Energy Treated sample was also known as The Trivedi Effect ${ }^{\circledR}$ Treated sample. Eighteen Biofield Energy Healers were remotely located in the U.S.A. and two of which was remotely located in Canada, while the test compound was located in the research laboratory of GVK Biosciences Pvt. Ltd., Hyderabad, India. The Trivedi Effect ${ }^{\circledR}$ - Energy of Consciousness Healing Treatment (Biofield Energy Healing Treatment) was provided for 5 minutes through the Healer's Unique Energy Transmission process remotely to the test compound, which was kept under laboratory conditions. None of the Biofield Energy Healers in this study visited the laboratory in person, nor had any contact with the compounds. Similarly, the control compound was subjected to "sham" healer for 5 minutes, under the same laboratory conditions. The sham healer did not have any knowledge about The Trivedi Effect ${ }^{\circledR}$ treatment. After that, The Trivedi Effect ${ }^{\circledR}$ treated and untreated samples were kept in similar sealed conditions and characterized thoroughly by LC-MS and NMR spectroscopy.

\subsection{Characterization}

\subsubsection{Liquid Chromatography Mass Spectrometry (LC-MS) Analysis}

Liquid chromatography was performed using The Waters ${ }^{\circledR}$ ACQUITY UPLC, Milford, MA, USA equipped with a binary pump (The Waters ${ }^{\circledR}$ BSM HPLC pump), autosampler, column heater and a photo-diode array (PDA) detector. The column used for the study was a reversed phase Acquity BEH shield RP C18 (150 X $3.0 \mathrm{~mm}, 2.5 \mu \mathrm{m})$. The column temperature was kept constant at $40^{\circ} \mathrm{C}$. The mobile phase was $2 \mathrm{mM}$ ammonium acetate in water as mobile phase $\mathrm{A}$ and acetonitrile as mobile phase B. Chromatographic separation was achieved with following gradient program: 0 min $5 \% \mathrm{~B} ; 1 \mathrm{~min}-5 \% \mathrm{~B} ; 15 \mathrm{~min}-97 \% \mathrm{~B} ; 20 \mathrm{~min}-97 \% \mathrm{~B} ; 21 \mathrm{~min}$ $-5 \% \mathrm{~B} ; 25 \mathrm{~min}-5 \% \mathrm{~B}$. The flow rate was at a constant flow rate of $0.4 \mathrm{~mL} / \mathrm{min}$. The control and treated samples were dissolved in a mixture of water and methanol $(60: 40 \mathrm{v} / \mathrm{v})$ to prepare a $1 \mathrm{mg} / \mathrm{mL}$ stock solution. An aliquot of $2 \mu \mathrm{L}$ of the stock solution was used for analysis by LC-ESI-MS and the total run time was $25 \mathrm{~min}$. Mass spectrometric analysis was accompanied on a Triple Quad (Waters Quattro Premier XE, USA) mass spectrometer equipped with an electrospray ionization (ESI) source with the following parameters: electrospray capillary voltage $3.5 \mathrm{kV}$; source temperature $100^{\circ} \mathrm{C}$; desolvation temperature $350^{\circ} \mathrm{C}$; cone voltage $30 \mathrm{~V}$; desolvation gas flow $1000 \mathrm{~L} / \mathrm{h}$ and cone gas flow $60 \mathrm{~L} / \mathrm{h}$.
Nitrogen was used in the electrospray ionization source. The multiplier voltage was set at $650 \mathrm{~V}$. LC-MS was taken in positive ionization mode and with the full scan $(\mathrm{m} / \mathrm{z} 50$ 1400). The total ion chromatogram, \% peak area and mass spectrum of the individual peak (appeared in LC) were recorded.

\subsubsection{Isotopic Abundance Ratio Analysis}

The relative intensity of the peak in the mass spectra is directly proportional to the relative isotopic abundance of the molecule and the isotopic abundance ratio analysis was followed the scientific literature reported [36-39] method described as below:

$\mathrm{P}_{\mathrm{M}}$ stands for the relative peak intensity of the parent molecular ion $\left[\mathrm{M}^{+}\right]$expressed in percentage. In other way, it indicates the probability to $A$ elements having only one natural isotope in appreciable abundance (for e.g. ${ }^{12} \mathrm{C},{ }^{1} \mathrm{H}$, ${ }^{16} \mathrm{O},{ }^{24} \mathrm{Mg}$, etc.) contributions to the mass of the parent molecular ion $\left[\mathrm{M}^{+}\right]$.

$\mathrm{P}_{\mathrm{M}+1}$ represents the relative peak intensity of the isotopic molecular ion $\left[(\mathrm{M}+1)^{+}\right]$expressed in percentage

$=\left(\right.$ no. of $\left.{ }^{13} \mathrm{C} \times 1.1 \%\right)+\left(\right.$ no. of $\left.{ }^{15} \mathrm{~N} \times 0.40 \%\right)+\left(\right.$ no. of ${ }^{2} \mathrm{H} \times$ $0.015 \%)+\left(\right.$ no. of $\left.{ }^{17} \mathrm{O} \times 0.04 \%\right)+\left(\right.$ no. of $\left.{ }^{25} \mathrm{Mg} \times 12.66 \%\right)$

i.e. the probability to $A+1$ elements having an isotope that has one mass unit heavier than the most abundant isotope (for e.g. ${ }^{13} \mathrm{C},{ }^{2} \mathrm{H},{ }^{17} \mathrm{O},{ }^{25} \mathrm{Mg}$, etc.) contributions to the mass of the isotopic molecular ion $\left[(\mathrm{M}+1)^{+}\right]$.

$\mathrm{P}_{\mathrm{M}+2}$ represents the relative peak intensity of the isotopic molecular ion $\left[(\mathrm{M}+2)^{+}\right]$expressed in the percentage

$=\left(\right.$ no. of $\left.{ }^{18} \mathrm{O} \times 0.20 \%\right)+\left(\right.$ no. of $\left.{ }^{26} \mathrm{Mg} \times 13.94 \%\right)$

i.e. the probability to have $A+2$ elements having an isotope that has two mass unit heavier than the most abundant isotope (for e.g. ${ }^{18} \mathrm{O},{ }^{26} \mathrm{Mg}$, etc.) contributions to the mass of isotopic molecular ion $\left[(\mathrm{M}+2)^{+}\right]$.

Table 1. The isotopic composition (i.e. the natural isotopic abundance) of the elements.

\begin{tabular}{llllll}
\hline Element & Symbol & Mass & $\begin{array}{l}\text { \% Natural } \\
\text { Abundance }\end{array}$ & $\begin{array}{l}\boldsymbol{A}+\mathbf{1} \\
\text { Factor }\end{array}$ & $\begin{array}{l}\boldsymbol{A}+\mathbf{2} \\
\text { Factor }\end{array}$ \\
\hline Hydrogen & ${ }^{1} \mathrm{H}$ & 1 & 99.9885 & & \\
& ${ }^{2} \mathrm{H}$ & 2 & 0.0115 & $0.015 \mathrm{n}_{\mathrm{H}}$ & \\
Carbon & ${ }^{12} \mathrm{C}$ & 12 & 98.892 & & \\
& ${ }^{13} \mathrm{C}$ & 13 & 1.108 & $1.1 \mathrm{n}_{\mathrm{C}}$ & \\
Oxygen & ${ }^{16} \mathrm{O}$ & 16 & 99.762 & & \\
& ${ }^{17} \mathrm{O}$ & 17 & 0.038 & $0.04 \mathrm{n}_{\mathrm{O}}$ & \\
& ${ }^{18} \mathrm{O}$ & 18 & 0.200 & & $0.20 \mathrm{n}_{\mathrm{O}}$ \\
Magnesium & ${ }^{24} \mathrm{Mg}$ & 24 & 78.99 & & \\
& ${ }^{25} \mathrm{Mg}$ & 25 & 10.00 & $12.66 \mathrm{n}_{\mathrm{Mg}}$ & \\
& ${ }^{26} \mathrm{Mg}$ & 26 & 11.01 & & $13.94 \mathrm{n}_{\mathrm{Mg}}$ \\
\hline
\end{tabular}

A represents element, $\mathrm{n}$ represents the number of the element (i.e. C, H. O, Mg, etc.)

The value of the natural isotopic abundance of the elements used here for the theoretical calculation are achieved from the scientific literature and presented in the Table $1[43,44]$.

Isotopic abundance ratio for $A+1$ elements $=\mathrm{P}_{\mathrm{M}+1} / \mathrm{P}_{\mathrm{M}}$

Similarly, isotopic abundance ratio for $A+2$ elements $=$ $\mathrm{P}_{\mathrm{M}+2} / \mathrm{P}_{\mathrm{M}}$ 
Percentage $(\%)$ change in isotopic abundance ratio $=$ $\left.\left[\left(\mathrm{IAR}_{\text {Treated }}-\mathrm{IAR}_{\text {Control }}\right) / \mathrm{IAR}_{\text {Control }}\right) \times 100\right]$,

Where, $\mathrm{IAR}_{\text {Treated }}=$ isotopic abundance ratio in the Biofield Energy Treated sample and $\mathrm{IAR}_{\text {Control }}=$ isotopic abundance ratio in the control sample.

\subsubsection{Nuclear Magnetic Resonance (NMR) Analysis}

${ }^{1} \mathrm{H}$ NMR spectra were recorded in a $400 \mathrm{MHZ}$ VARIAN FT-NMR spectrometer at room temperature. Data refer to solutions in $\mathrm{D}_{2} \mathrm{O}$ with the residual solvent protons as internal references. ${ }^{1} \mathrm{H}$ NMR multiplicities were designated as singlet (s), doublet (d), triplet (t), multiplet (m), and broad (br). ${ }^{13} \mathrm{C}$ NMR spectra were measured at $100 \mathrm{MHz}$ on a VARIAN FTNMR spectrometer at room temperature. Chemical shifts $(\delta)$ were in parts per million (ppm) relative to the solvent's residual proton chemical shift $\left(\mathrm{D}_{2} \mathrm{O}, \delta=4.65 \mathrm{ppm}\right)$ and solvent's residual carbon chemical shift $\left(\mathrm{D}_{2} \mathrm{O}, \delta=0 \mathrm{ppm}\right)$.

\section{Results and Discussion}

\subsection{Liquid Chromatography-Mass Spectrometry (LC-MS) Analysis}

The liquid chromatograms of both the control and treated magnesium gluconate.

(Figure 1) exhibited a sharp peak at the retention time $\left(\mathrm{R}_{\mathrm{t}}\right)$ of $1.52 \mathrm{~min}$. This result clearly indicated that the polarity/affinity of The Trivedi Effect $\left.{ }^{(}\right)$Biofield Energy Treated sample remained unchanged compared with the control sample.

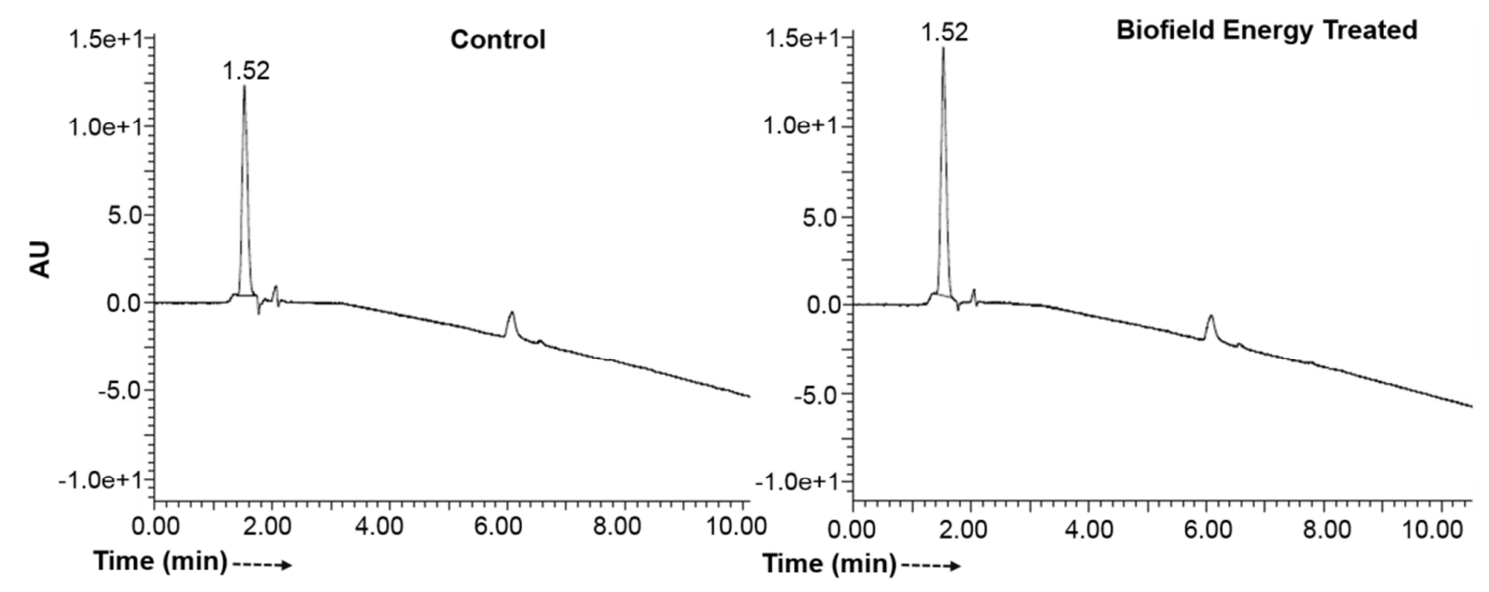

Figure 1. Liquid chromatograms of the control and The Trivedi Effect ${ }^{\circledR}$ - Biofield Energy Treated magnesium gluconate.

The ESI-MS spectra of both the control and treated magnesium gluconate at $\mathrm{R}_{\mathrm{t}}$ of 1.52 min as shown in the Figure 2 revealed the presence of the mass of magnesium gluconate at $m / z 415[\mathrm{M}+\mathrm{H}]^{+}$(calcd for $\mathrm{C}_{12} \mathrm{H}_{23} \mathrm{MgO}_{14}{ }^{+}, 415$ ).

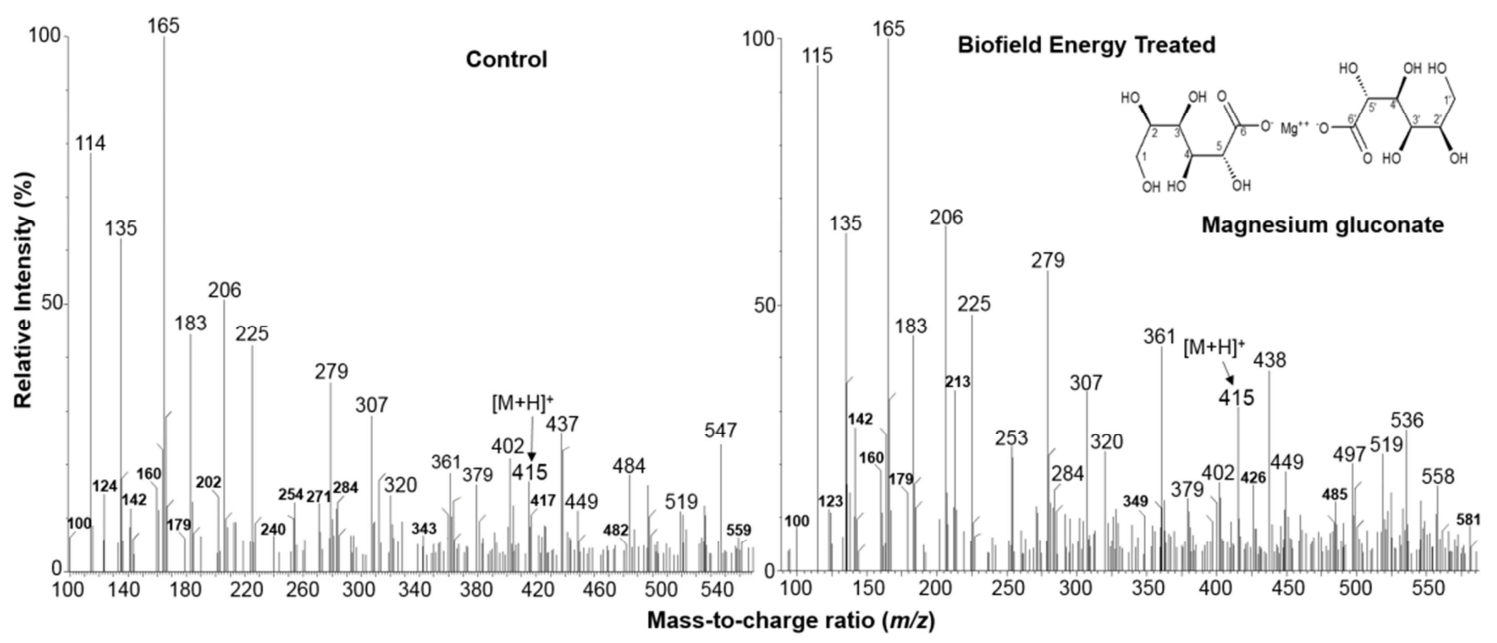

Figure 2. The ESI-MS spectra of the control and Biofield Energy Treated magnesium gluconate.

The typical fragment ion peaks in the lower $\mathrm{m} / \mathrm{z}$ region of the protonated magnesium gluconate ion $[\mathrm{M}]^{+}(\mathrm{m} / \mathrm{z} 415)$ were observed in both the control and the treated samples at $\mathrm{m} / \mathrm{z}$ $402\left[\mathrm{M}-\mathrm{H}_{2} \mathrm{O}+6 \mathrm{H}\right]^{+}$(calcd for $\mathrm{C}_{12} \mathrm{H}_{26} \mathrm{MgO}_{13}{ }^{4+}, 402$ ), 379 $\left[\mathrm{M}-2 \mathrm{H}_{2} \mathrm{O}+\mathrm{H}\right]^{+}$(calcd for $\left.\mathrm{C}_{12} \mathrm{H}_{19} \mathrm{MgO}_{12}{ }^{+}, 379\right), 361[\mathrm{M}-$ $\left.3 \mathrm{H}_{2} \mathrm{O}+\mathrm{H}\right]^{+}$(calcd for $\mathrm{C}_{12} \mathrm{H}_{17} \mathrm{MgO}_{11}{ }^{+}, 361$ ), $342\left[\mathrm{M}-4 \mathrm{H}_{2} \mathrm{O}\right]^{+}$ (calcd for $\mathrm{C}_{12} \mathrm{H}_{14} \mathrm{MgO}_{10}{ }^{2+}, 342$ ). By this way removing water along with other groups like alkyl, magnesium gluconate produces different fragment ion peaks at $\mathrm{m} / \mathrm{z} 320,307,284$, $279,225,206,183,179,165,135,123$, and 100 which were 
observed in the ESI-MS spectra of the control and treated samples (Figure 2).

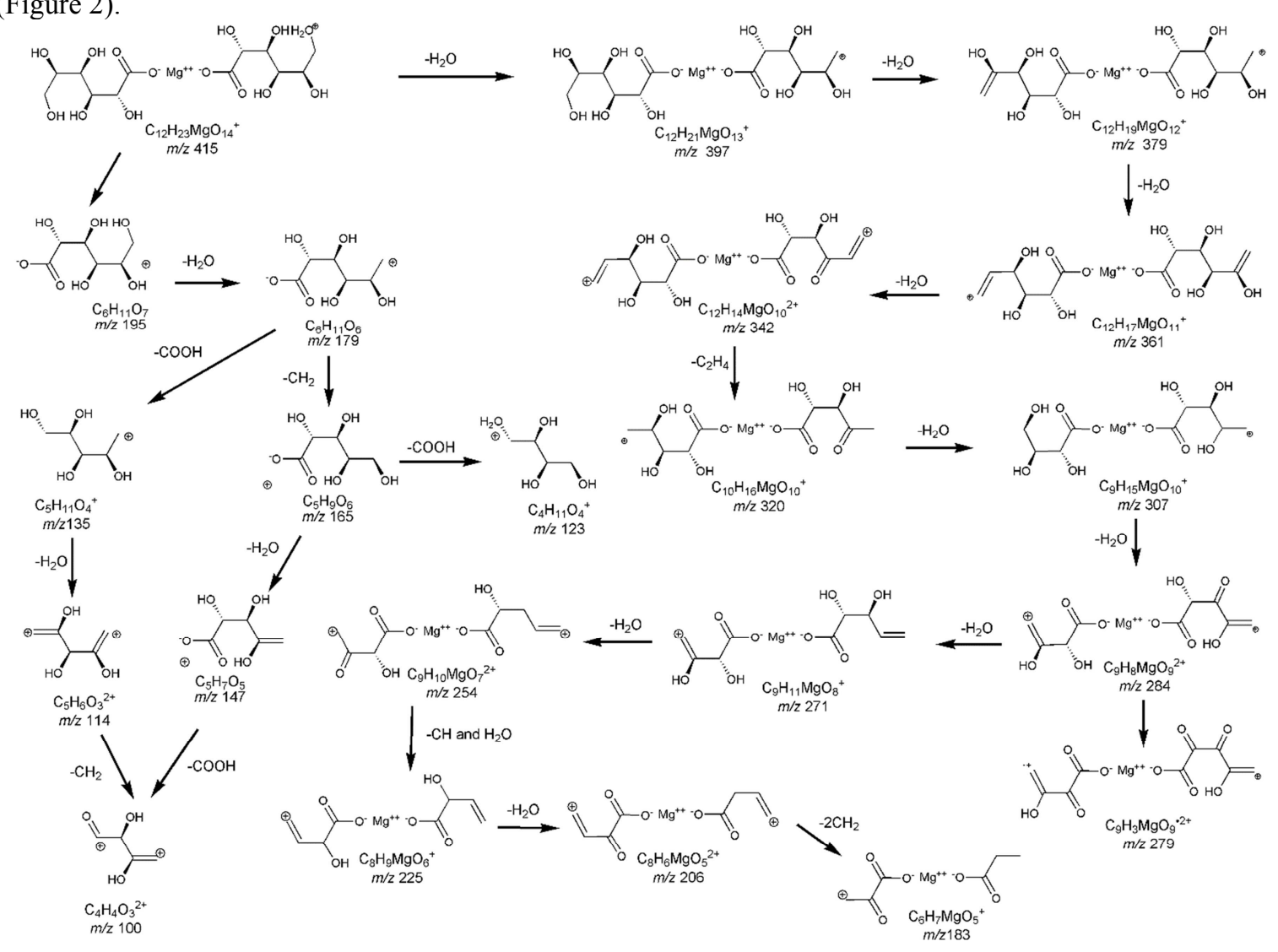

Figure 3. Proposed fragmentation pathway of magnesium gluconate.

These ions correspond to the following molecular formula $\mathrm{C}_{10} \mathrm{H}_{16} \mathrm{MgO}_{10}{ }^{+}, \mathrm{C}_{9} \mathrm{H}_{15} \mathrm{MgO}_{10}{ }^{+}, \mathrm{C}_{9} \mathrm{H}_{8} \mathrm{MgO}_{9}{ }^{2+}, \mathrm{C}_{9} \mathrm{H}_{3} \mathrm{MgO}_{9}{ }^{-2+}$, $\mathrm{C}_{8} \mathrm{H}_{9} \mathrm{MgO}_{6}^{+}, \mathrm{C}_{8} \mathrm{H}_{6} \mathrm{MgO}_{5}^{2+}, \mathrm{C}_{6} \mathrm{H}_{7} \mathrm{MgO}_{5}^{+}, \mathrm{C}_{6} \mathrm{H}_{11} \mathrm{O}_{6}^{+}, \mathrm{C}_{5} \mathrm{H}_{9} \mathrm{O}_{6}^{+}$, $\mathrm{C}_{5} \mathrm{H}_{11} \mathrm{O}_{4}^{+}, \mathrm{C}_{4} \mathrm{H}_{11} \mathrm{O}_{4}^{+}$, and $\mathrm{C}_{4} \mathrm{H}_{4} \mathrm{O}_{3}{ }^{2+}$ respectively as shown in the Figure 3. Two fragment ion peaks at $\mathrm{m} / \mathrm{z} 254$ and 114 that are corresponded to the molecular formula $\mathrm{C}_{9} \mathrm{H}_{10} \mathrm{MgO}_{7}{ }^{2+}$ and $\mathrm{C}_{5} \mathrm{H}_{6} \mathrm{O}_{3}{ }^{2+}$, respectively were observed in the control sample. Consequently, the treated sample exhibited fragment ions at $\mathrm{m} / \mathrm{z} 253$ and 115 that are corresponded to the molecular formula $\mathrm{C}_{9} \mathrm{H}_{9} \mathrm{MgO}_{7}{ }^{2+\bullet}$ and $\mathrm{C}_{5} \mathrm{H}_{7} \mathrm{O}_{3}^{+}$, respectively. The ESIMS spectra of the control and treated samples (Figure 2) displayed almost similar type fragmentation pattern. The fragment ion peak at $\mathrm{m} / z 165$ corresponding to $\mathrm{C}_{5} \mathrm{H}_{9} \mathrm{O}_{6}{ }^{+}$ exhibited $100 \%$ relative peak intensity in both the control and the treated ESI-MS spectra (Figure 2). The relative peak intensities of the other ion peaks in The Trivedi Effect ${ }^{\circledR}$ Treated sample were significantly altered compared with the control sample.

\subsection{Isotopic Abundance Ratio Analysis}

The molecular formula of magnesium gluconate is $\mathrm{C}_{12} \mathrm{H}_{22} \mathrm{MgO}_{14}$. But, in the ESI-MS spectra, it existed as a protonated molecular ion at $\mathrm{m} / \mathrm{z} 415\left(\mathrm{C}_{12} \mathrm{H}_{23} \mathrm{MgO}_{14}{ }^{+}\right)$ showing $16.76 \%$ (control) and $30.75 \%$ (treated) relative intensities. The theoretical calculation of $\mathrm{P}_{\mathrm{M}+1}$ and $\mathrm{P}_{\mathrm{M}+2}$ for the protonated magnesium gluconate was presented as below:

$$
\begin{gathered}
\mathrm{P}\left({ }^{13} \mathrm{C}\right)=\left[\begin{array}{r}
(12 \times 1.1 \%) \times 16.76 \%\left(\text { the actual size of the } \mathrm{M}^{+}\right. \\
\text {peak })] / 100 \%=2.21 \%
\end{array}\right. \\
\mathrm{P}\left({ }^{2} \mathrm{H}\right)=[(23 \times 0.015 \%) \times 16.76 \%] / 100 \%=0.06 \% \\
\mathrm{P}\left({ }^{17} \mathrm{O}\right)=[(14 \times 0.04 \%) \times 16.76 \%] / 100 \%=0.09 \% \\
\mathrm{P}\left({ }^{25} \mathrm{Mg}\right)=[(1 \times 12.66 \%) \times 16.76 \%] / 100 \%=2.12 \%
\end{gathered}
$$

$\mathrm{P}_{\mathrm{M}+1}$ i.e. ${ }^{13} \mathrm{C},{ }^{2} \mathrm{H},{ }^{17} \mathrm{O}$, and ${ }^{25} \mathrm{Mg}$ contributions from $\left(\mathrm{C}_{12} \mathrm{H}_{23} \mathrm{MgO}_{14}\right)^{+}$to $m / z 416=4.48 \%$

From the above calculation, it has been found that ${ }^{13} \mathrm{C}$ and ${ }^{25} \mathrm{Mg}$ have major contribution to $\mathrm{m} / \mathrm{z} 416$.

In the similar way, $\mathrm{P}_{\mathrm{M}+2}$ can be calculated as follow:

$$
\begin{gathered}
\mathrm{P}\left({ }^{18} \mathrm{O}\right)=[(14 \times 0.20 \%) \times 16.76 \%] / 100 \%=0.47 \% \\
\mathrm{P}\left({ }^{26} \mathrm{Mg}\right)=[(1 \times 13.94 \%) \times 16.76 \%] / 100 \%=2.34 \%
\end{gathered}
$$

So, $\mathrm{P}_{\mathrm{M}+2}$ i.e. ${ }^{18} \mathrm{O}$ and ${ }^{26} \mathrm{Mg}$ contributions from $\left(\mathrm{C}_{12} \mathrm{H}_{23} \mathrm{MgO}_{14}\right)^{+}$to $m / z 417=2.81 \%$.

But the experimental data showed the difference due to the complexity in the structure. LC-MS spectra of the control and treated samples indicated the presence of the mass for the protonated magnesium gluconate $\left(\mathrm{m} / z\right.$ 415). Hence, $\mathrm{P}_{\mathrm{M}}, \mathrm{P}_{\mathrm{M}+1}$, $\mathrm{P}_{\mathrm{M}+2}$ for magnesium gluconate at $\mathrm{m} / \mathrm{z} 415,416$ and 417 of the control and treated samples were obtained from the observed 
relative peak intensities of $\left[\mathrm{M}^{+}\right],\left[(\mathrm{M}+1)^{+}\right]$, and $\left[(\mathrm{M}+2)^{+}\right]$

presented in Table 2.

peaks, respectively in the respective ESI-MS spectra are

Table 2. Isotopic abundance analysis results of the magnesium gluconate ion in the control and The Trivedi Effect ${ }^{\circledR}$ Treated sample.

\begin{tabular}{lll}
\hline Parameter & Control sample & The Trivedi Effect $^{\circledR}$ Treated sample \\
\hline $\mathrm{P}_{\mathrm{M}}$ at $m / z 415(\%)$ & 16.76 & 30.75 \\
$\mathrm{P}_{\mathrm{M}+1}$ at $m / z 416(\%)$ & 8.29 & 9.74 \\
$\mathrm{P}_{\mathrm{M}+1} / \mathrm{P}_{\mathrm{M}}$ & 0.4946 & 0.3167 \\
\% Change of isotopic abundance ratio $\left(\mathrm{P}_{\mathrm{M}+1} / \mathrm{P}_{\mathrm{M}}\right)$ with respect to the control sample & & -35.97 \\
$\mathrm{P}_{\mathrm{M}+2}$ at $m / z 417(\%)$ & 10.53 & 6.42 \\
$\mathrm{P}_{\mathrm{M}+2} / \mathrm{P}_{\mathrm{M}}$ & 0.6283 & 0.2088 \\
$\%$ Change of isotopic abundance ratio $\left(\mathrm{P}_{\mathrm{M}+2} / \mathrm{P}_{\mathrm{M}}\right)$ with respect to the control sample & & -66.77 \\
\hline
\end{tabular}

$\mathrm{P}_{\mathrm{M}}=$ the relative peak intensity of the parent molecular ion $\left[\mathrm{M}^{+}\right] ; \mathrm{P}_{\mathrm{M}+1}=$ the relative peak intensity of the isotopic molecular ion $\left[(\mathrm{M}+1)^{+}\right], \mathrm{P}_{\mathrm{M}+2}=$ the relative peak intensity of the isotopic molecular ion $\left[(\mathrm{M}+2)^{+}\right]$, and $\mathrm{M}=$ mass of the parent molecule.

The isotopic abundance ratios of $\mathrm{P}_{\mathrm{M}+1} / \mathrm{P}_{\mathrm{M}}$ and $\mathrm{P}_{\mathrm{M}+2} / \mathrm{P}_{\mathrm{M}}$ in the treated sample were significantly decreased by $35.97 \%$ and $66.77 \%$, respectively compared with the control sample (Table 2). So, ${ }^{13} \mathrm{C},{ }^{2} \mathrm{H},{ }^{17} \mathrm{O}$, and ${ }^{25} \mathrm{Mg}$ contributions from $\left(\mathrm{C}_{12} \mathrm{H}_{23} \mathrm{MgO}_{14}\right)^{+}$to $\mathrm{m} / \mathrm{z} 416 ;{ }^{18} \mathrm{O}$ and ${ }^{26} \mathrm{Mg}$ contributions from $\left(\mathrm{C}_{12} \mathrm{H}_{23} \mathrm{MgO}_{14}\right)^{+}$to $\mathrm{m} / z 417$ in The Trivedi Effect ${ }^{\circledR}$ Treated sample were significantly reduced compared with the control sample.

Table 3. Possible isotopic bond and their effect in the vibrational energy in magnesium gluconate molecule.

\begin{tabular}{lllll}
\hline $\begin{array}{l}\text { SL } \\
\text { No. }\end{array}$ & $\begin{array}{l}\text { Probable } \\
\text { isotopic bond }\end{array}$ & $\begin{array}{l}\text { Isotope } \\
\text { type }\end{array}$ & $\begin{array}{l}\text { Reduced } \\
\text { mass }(\boldsymbol{\mu})\end{array}$ & $\begin{array}{l}\text { Zero point vibrational } \\
\text { energy }\left(\boldsymbol{E}_{\boldsymbol{O}}\right)\end{array}$ \\
\hline 1 & ${ }^{12} \mathrm{C}-{ }^{12} \mathrm{C}$ & Lighter & 6.00 & Higher \\
2 & ${ }^{13} \mathrm{C}-{ }^{12} \mathrm{C}$ & Heavier & 6.26 & Smaller \\
3 & ${ }^{1} \mathrm{H}-{ }^{12} \mathrm{C}$ & Lighter & 0.92 & Higher \\
4 & ${ }^{2} \mathrm{H}-^{-12} \mathrm{C}$ & Heavier & 1.04 & Smaller \\
5 & ${ }^{12} \mathrm{C}-{ }^{16} \mathrm{O}$ & Lighter & 6.86 & Higher \\
6 & ${ }^{13} \mathrm{C}-{ }^{16} \mathrm{O}$ & Heavier & 7.17 & Smaller \\
7 & ${ }^{12} \mathrm{C}-{ }^{17} \mathrm{O}$ & Heavier & 7.03 & Smaller \\
8 & ${ }^{12} \mathrm{C}-{ }^{18} \mathrm{O}$ & Heavier & 7.20 & Smaller \\
9 & ${ }^{16} \mathrm{O}-{ }^{1} \mathrm{H}$ & Lighter & 0.94 & Higher \\
10 & ${ }^{16} \mathrm{O}-{ }^{-2} \mathrm{H}$ & Heavier & 1.78 & Smaller \\
11 & ${ }^{24} \mathrm{Mg}-{ }^{16} \mathrm{O}$ & Lighter & 9.60 & Higher \\
12 & ${ }^{25} \mathrm{Mg}-{ }^{16} \mathrm{O}$ & Heavier & 9.76 & Smaller \\
13 & ${ }^{26} \mathrm{Mg}-{ }^{16} \mathrm{O}$ & Heavier & 9.91 & Smaller \\
14 & ${ }^{24} \mathrm{Mg}-{ }^{17} \mathrm{O}$ & Heavier & 9.95 & Smaller \\
15 & ${ }^{24} \mathrm{Mg}-{ }^{18} \mathrm{O}$ & Heavier & 10.29 & Smaller \\
\hline
\end{tabular}

Scientific literature $[37-39,45]$ reported that the vibrational energy is closely related with the reduced mass $(\mu)$ of the compound and the alteration of the vibrational energy can affect the several properties like physicochemical, thermal properties of the molecule. The relation between the vibrational energy and the reduced mass $(\mu)$ for a diatomic molecule (Equation 1) is expressed as below $[42,45]$ :

$$
E_{o}=\frac{h}{4 \pi} \sqrt{\frac{f}{\mu}}
$$

Where $E_{0}=$ the vibrational energy of a harmonic oscillator at absolute zero or zero point energy

$f=$ force constant

$$
\mu=\text { reduced mass }=\frac{m_{a} m_{a}}{m_{a}+m_{a}}
$$

Where $m_{a}$ and $m_{b}$ are the masses of the constituent atoms.

The alteration in the isotopic abundance ratios of ${ }^{13} \mathrm{C} /{ }^{12} \mathrm{C}$ for $\mathrm{C}-\mathrm{O} ;{ }^{2} \mathrm{H} /{ }^{1} \mathrm{H}$ for $\mathrm{C}-\mathrm{H}$ and $\mathrm{O}-\mathrm{H}$ bonds; $;{ }^{17} \mathrm{O} /{ }^{16} \mathrm{O}$ and ${ }^{18} \mathrm{O} /{ }^{16} \mathrm{O}$ for $\mathrm{C}$-O bond; ${ }^{25} \mathrm{Mg} /{ }^{24} \mathrm{Mg},{ }^{26} \mathrm{Mg} /{ }^{24} \mathrm{Mg},{ }^{17} \mathrm{O} /{ }^{16} \mathrm{O}$ and ${ }^{18} \mathrm{O} /{ }^{16} \mathrm{O}$ for $\mathrm{Mg}-\mathrm{O}$ bond have the significant impact on the ground state vibrational energy of the molecule due to the higher reduced mass $(\mu)$ as shown in the Table 4 that leads to the isotope effects of the molecule.

Mass spectroscopic analysis of the several organic compounds revealed that the isotopic abundance of $[\mathrm{M}+1]^{+}$and $[\mathrm{M}+2]^{+}$ions were increased or decreased, thereby suggesting the change in number of neutrons in the molecule. It was then postulated to the alterations in atomic mass and atomic charge through possible mediation of neutrino oscillation [37-39, 46]. Thus, it is assumed that The Trivedi Effect ${ }^{\circledR}$ - Biofield Energy Healing Treatment might offer the required energy for the neutrino oscillations. The changes of neutrinos inside the molecule in turn modified the particle size, chemical reactivity, density, thermal behavior, selectivity, binding energy, etc. [46]. Kinetic isotope effect that is resultant from the variation in the isotopic abundance ratio of one of the atoms in the reactants in a chemical reaction is very useful to study the reaction mechanism as well as for understanding the enzymatic transition state and all aspects of enzyme mechanism that is supportive for designing enormously effective and specific inhibitors $[42,45,47]$. As magnesium is an essential cofactor for various enzymatic reactions, The Trivedi Effect ${ }^{\mathbb{B}}$ Treated magnesium gluconate that had altered isotopic abundance ratio might be advantageous for the study of enzyme mechanism as well as support in the designing of novel potent enzyme inhibitors.

\subsection{Nuclear Magnetic Resonance (NMR) Analysis}

The ${ }^{1} \mathrm{H}$ and ${ }^{13} \mathrm{C}$ NMR spectra of the control and treated magnesium gluconate are presented in the Figures 4 and 5, respectively. NMR assignments of the control and Biofield 
Energy Treated magnesium gluconate are presented in the Table 4.

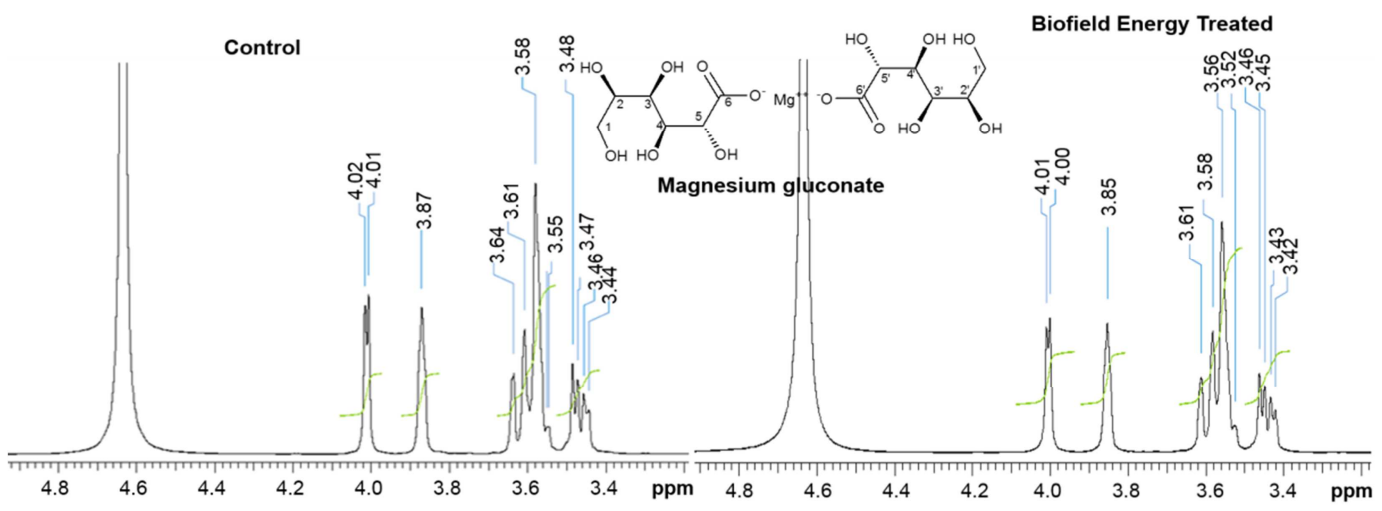

Figure 4. The ${ }^{1} H$ NMR spectra of the control and Biofield Energy Treated magnesium gluconate.

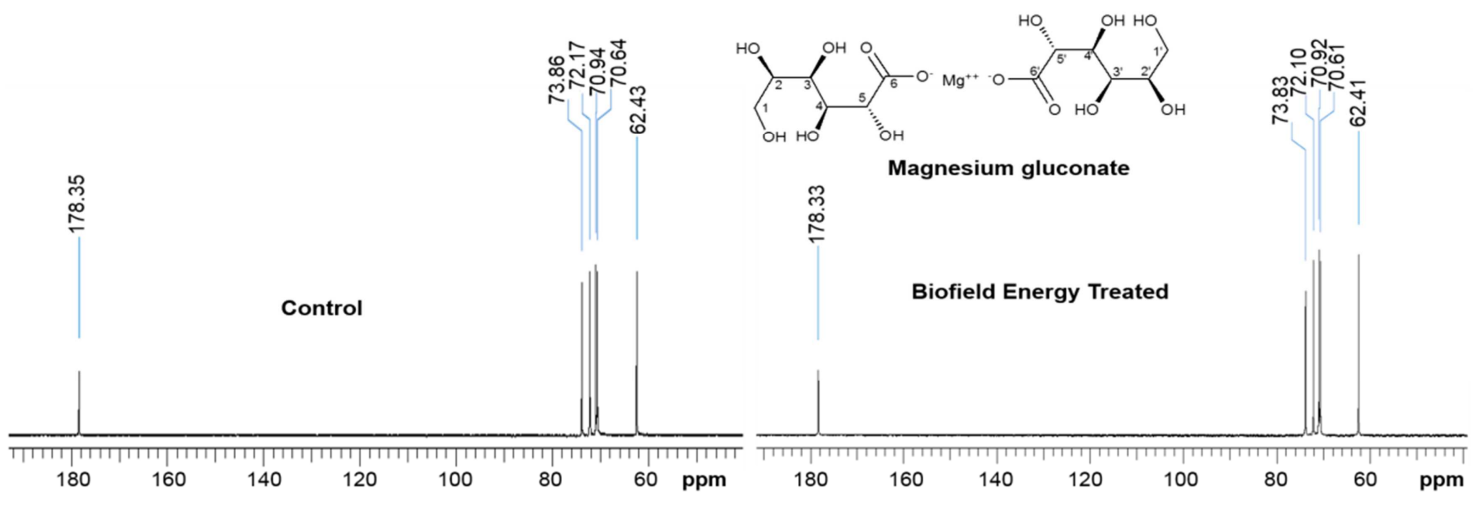

Figure 5. The ${ }^{13} \mathrm{C} N M R$ spectra of the control and Biofield Energy Treated magnesium gluconate.

Table 4. ${ }^{1} \mathrm{H}$ NMR and ${ }^{13} \mathrm{C}$ NMR spectroscopic data of both the control and Biofield Energy Treated of magnesium gluconate.

\begin{tabular}{|c|c|c|c|c|c|}
\hline \multirow[t]{2}{*}{ Position } & \multicolumn{3}{|c|}{${ }^{1} \mathrm{H}$ NMR $\delta(\mathrm{ppm})$} & \multicolumn{2}{|c|}{${ }^{13} \mathrm{C}$ NMR $\delta(\mathrm{ppm})$} \\
\hline & Number & Control & Treated & Control & Treated \\
\hline $1,1^{\prime}$ & $4 \mathrm{H}^{*}$ & $3.64(\mathrm{br} \mathrm{s}), 3.46(\mathrm{dd}, J=12,4 \mathrm{~Hz})$ & $3.61(\mathrm{br} \mathrm{s}), 3.44(\mathrm{dd}, J=12,4 \mathrm{~Hz})$ & 62.43 & 62.41 \\
\hline $2,2^{\prime}$ & $2 \mathrm{H}^{*}$ & $3.58(\mathrm{br} \mathrm{s})$ & $3.56(\mathrm{br} \mathrm{s})$ & 70.64 & 70.61 \\
\hline $3,3^{\prime}$ & $2 \mathrm{H}^{*}$ & 3.61 (br s) & $3.58(\mathrm{br} \mathrm{s})$ & 70.94 & 70.92 \\
\hline $4,4^{\prime}$ & $2 \mathrm{H}$ & 3.87 (br s) & $3.85(\mathrm{br} \mathrm{s})$ & 72.17 & 72.10 \\
\hline $5,5^{\prime}$ & $2 \mathrm{H}$ & $4.02(\mathrm{~d}, J=4 \mathrm{~Hz})$ & $4.01(\mathrm{~d}, J=4 \mathrm{~Hz})$ & 73.86 & 73.83 \\
\hline $6,6^{\prime}$ & -- & & -- & 178.35 & 178.33 \\
\hline
\end{tabular}

br- broad, s- singlet, and d-doublet, and dd- doublet of doublet, ${ }^{*}$ These assignments can be switched.

Although magnesium gluconate contains a large number of hydroxyl $(\mathrm{OH})$ groups, the proton spectra of both the control and treated samples did not show any signal for the hydroxyl protons due to the replacement of the hydroxyl protons by deuterium from deuterated water, which was used as solvent for spectra recording. The signals for the protons coupling of $\mathrm{CH}_{2}$ group and adjacent $\mathrm{CH}$ protons (2-5) in the gluconic acid portion were observed in the control sample in the range of $\delta 3.46$ to $4.02 \mathrm{ppm}$ (Table 4), which was almost in accordance with the proton spectrum of sodium gluconate [48]. Consequently, the proton signals for $\mathrm{CH}_{2}$ and $\mathrm{CH}$ groups for the treated sample were observed in the range of $\delta$ 3.44 to $4.01 \mathrm{ppm}$ (Table 4). Similarly, the carbon signals for $\mathrm{CO}$ group, $\mathrm{CH}_{2}$ and $\mathrm{CH}$ groups in the ${ }^{13} \mathrm{C}$ NMR spectrum of the treated sample were slightly decreased compared with the control sample (Table 4). So, the structure of the magnesium gluconate in the treated samples remained same with the control sample.

\section{Conclusions}

The present research work established nicely the structural characterization of magnesium gluconate using LC-MS and NMR techniques and a significantly impact of The Trivedi Effect $^{\circledR}$ - Energy of Consciousness Healing Treatment (Biofield Energy Healing Treatment) on the isotopic abundance ratios of $\mathrm{P}_{\mathrm{M}+1} / \mathrm{P}_{\mathrm{M}}$ and $\mathrm{P}_{\mathrm{M}+2} / \mathrm{P}_{\mathrm{M}}$. The LC-MS analysis of the both control and treated samples showed the presence of the mass of the protonated magnesium gluconate at $\mathrm{m} / \mathrm{z} 415$ at the retention time of $1.52 \mathrm{~min}$ with the nearly same type of fragmentation. The relative peak intensities of the fragment ions of the treated sample were significantly altered 
compared with the control sample. The isotopic abundance ratios of $\mathrm{P}_{\mathrm{M}+1} / \mathrm{P}_{\mathrm{M}}\left({ }^{2} \mathrm{H} /{ }^{1} \mathrm{H}\right.$ or ${ }^{13} \mathrm{C} /{ }^{12} \mathrm{C}$ or ${ }^{17} \mathrm{O} /{ }^{16} \mathrm{O}$ or $\left.{ }^{25} \mathrm{Mg} /{ }^{24} \mathrm{Mg}\right)$ and $\mathrm{P}_{\mathrm{M}+2} / \mathrm{P}_{\mathrm{M}} \quad\left({ }^{18} \mathrm{O} /{ }^{16} \mathrm{O}\right.$ or $\left.{ }^{26} \mathrm{Mg} /{ }^{24} \mathrm{Mg}\right)$ were significantly reduced in the treated sample by $35.97 \%$ and $66.77 \%$, respectively compared with the control sample. Briefly, ${ }^{13} \mathrm{C}$, ${ }^{2} \mathrm{H},{ }^{17} \mathrm{O}$, and ${ }^{25} \mathrm{Mg}$ contributions from $\left(\mathrm{C}_{12} \mathrm{H}_{23} \mathrm{MgO}_{14}\right)^{+}$to $\mathrm{m} / \mathrm{z}$ $416 ;{ }^{18} \mathrm{O}$ and ${ }^{26} \mathrm{Mg}$ contributions from $\left(\mathrm{C}_{12} \mathrm{H}_{23} \mathrm{MgO}_{14}\right)^{+}$to $\mathrm{m} / \mathrm{z}$ 417 in the treated sample were significantly decreased compared with the control sample. The treated sample might exhibit isotope effects such as altered physicochemical and thermal properties, rate of the reaction, selectivity and binding energy due to its reduced isotopic abundance ratios of $\mathrm{P}_{\mathrm{M}+1} / \mathrm{P}_{\mathrm{M}}$ and $\mathrm{P}_{\mathrm{M}+2} / \mathrm{P}_{\mathrm{M}}$ compared with the control sample. The treated magnesium gluconate might be helpful to understand the enzymatic reactions as well as design the novel potent enzyme inhibitors by using its kinetic isotope effects. Besides, The Trivedi Effect ${ }^{\mathbb{R}}$ - Energy of Consciousness Healing Treatment (Biofield Energy Healing Treatment) could be a useful approach in the design of better nutraceutical and/or pharmaceutical formulations that can offer significant therapeutic responses against various diseases such as diabetes mellitus, allergies and septic shock, stress-related disorders like sleep disorder, insomnia, anxiety, depression, Attention Deficit Disorder (ADD), Attention Deficit Hyperactive Disorder (ADHD), mental restlessness (mind chattering), brain frog, low libido, impotency, lack of motivation, mood swings, fear of the future, confusion, migraines, headaches, forgetfulness, overwhelm, loneliness, worthlessness, indecisiveness, frustration, irritability, chronic fatigue, obsessive/compulsive behavior and panic attacks, inflammatory diseases and immunological disorders like Lupus, Systemic Lupus Erythematosus, Hashimoto Thyroiditis, Type 1 Diabetes, Asthma, Chronic peptic ulcers, Tuberculosis, Hepatitis, Chronic active hepatitis, Celiac Disease (gluten-sensitive enteropathy), Addison Disease, Crohn's disease, Graves' Disease, Pernicious and Aplastic Anemia, Sjogren Syndrome, Irritable Bowel Syndrome (IBS), Multiple Sclerosis, Rheumatoid arthritis, Chronic periodontitis, Ulcerative colitis, Chronic sinusitis, Myasthenia Gravis, Atherosclerosis, Vasculitis, Dermatitis, Diverticulitis, Rheumatoid Arthritis, Reactive Arthritis, Alopecia Areata, Psoriasis, Scleroderma, Fibromyalgia, Chronic Fatigue Syndrome and Vitiligo, agingrelated diseases like cardiovascular disease, arthritis, cancer, Alzheimer's disease, dementia, cataracts, osteoporosis, diabetes, hypertension, glaucoma, hearing loss, Parkinson's Disease, Huntington's Disease, Prion Disease, Motor Neurone Disease, Spinocerebellar Ataxia, Spinal muscular atrophy, Amyotrophic lateral sclerosis, Friedreich's Ataxia and Lewy Body Disease; chronic infections and many more.

\section{Abbreviations}

A: Element; LC-MS: Liquid chromatography-mass spectrometry; M: Mass of the parent molecule; $m / z$ : Mass-tocharge ratio; $n$ : Number of the element; NMR: Nuclear magnetic resonance spectroscopy; $\mathrm{P}_{\mathrm{M}}$ : The relative peak intensity of the parent molecular ion $\left[\mathrm{M}^{+}\right] ; \mathrm{P}_{\mathrm{M}+1}$ : The relative peak intensity of isotopic molecular ion $\left.\left[(\mathrm{M}+1)^{+}\right]\right) ; \mathrm{P}_{\mathrm{M}+2}$ : The relative peak intensity of isotopic molecular ion $\left.\left[(\mathrm{M}+2)^{+}\right]\right)$; $\mathrm{R}_{\mathrm{t}}$ : Retention time.

\section{Acknowledgements}

The authors are grateful to GVK Biosciences Pvt. Ltd., Trivedi Science, Trivedi Global, Inc. and Trivedi Master Wellness for their assistance and support during this work.

\section{References}

[1] Birch NJ (1990) Magnesium in biology and medicine: an overview in Metal ions in biological systems, Volume 26: Compendium on magnesium and its role in biology, nutrition and physiology, Sigel H, Sigel A (Eds.), Marcel Dekker Inc., New York, pp. 105-115.

[2] Garfinkel L, Garfinkel D (1985) Magnesium regulation of the glycolytic pathway and the enzymes involved. Magnesium 4: 60-72.

[3] Choi MK, Weaver CM (2017) Daily intake of magnesium and its relation to urinary excretion in korean healthy adults consuming self-selected diets. Biol Trace Elem Res 176, 105113.

[4] Gröber U, Schmidt J, Kisters K (2015) Magnesium in prevention and therapy. Nutrients 7: 8199-8226.

[5] William JH, Danziger J (2016) Magnesium deficiency and proton-pump inhibitor use: A clinical review. J Clin Pharmacol 56: 660-668.

[6] Guerrera MP, Volpe SL, Mao JJ (2009) Therapeutic uses of magnesium. Am Fam Physician 80: 157-162.

[7] Fleming TE, Mansmann Jr HC (1999) Methods and compositions for the prevention and treatment of diabetes mellitus. United States Patent 5871769, 1-10.

[8] Fleming TE, Mansmann Jr HC (1999) Methods and compositions for the prevention and treatment of immunological disorders, inflammatory diseases and infections. United States Patent 5939394, 1-11.

[9] Weglicki WB (2000) Intravenous magnesium gluconate for treatment of conditions caused by excessive oxidative stress due to free radical distribution. United States Patent 6100297, $1-6$.

[10] Turner RJ, Dasilva KW, O'Connor C, van den Heuvel C, Vink R (2004) Magnesium gluconate offers no more protection than magnesium sulphate following diffuse trau-matic braininjury in rats. J Am Coll Nutr 23: 541S-544S.

[11] Martin RW, Martin JN Jr, Pryor JA, Gaddy DK, Wiser WL, Morrison JC (1988) Comparison of oral ritodrine and magnesium gluconate for ambulatory tocolysis. Am J Obstet Gynecol 158: 1440-1445.

[12] Lee KH, Chung SH, Song JH, Yoon JS, Lee J, Jung MJ, Kim JH (2013) Cosmetic compositions for skin-tightening and method of skin-tightening using the same. United States Patent 8580741 B2. 
[13] Coudray C, Rambeau M, Feillet-Coudray C, Gueux E, Tressol JC, Mazur A, Rayssiguier Y (2005) Study of magnesium bioavailability from ten organic and inorganic $\mathrm{Mg}$ salts in $\mathrm{Mg}$ depleted rats using a stable isotope approach. Magnes Res 18: 215-223.

[14] Stenger VJ (1999) Bioenergetic fields. Sci Rev Alternative Med 3.

[15] Rogers, M (1989) "Nursing: A Science of Unitary Human Beings." In J. P. Riehl-Sisca (ed.) Conceptual Models for Nursing Practice. $3^{\text {rd }}$ Edn. Norwark: Appleton \& Lange.

[16] Sances F, Flora E, Patil S, Spence A, Shinde V (2013) Impact of biofield treatment on ginseng and organic blueberry yield. Agrivita 35: 22-29.

[17] Warber SL, Cornelio D, Straughn, J, Kile G (2004) Biofield energy healing from the inside. J Altern Complement Med 10: 1107-1113.

[18] Koithan M (2009) Introducing complementary and alternative therapies. J Nurse Pract 5: 18-20.

[19] Trivedi MK, Branton A, Trivedi D, Nayak G, Mondal SC, Jana S (2015) Effect of biofield treated energized water on the growth and health status in chicken (Gallus gallus domesticus). Poult Fish Wildl Sci 3: 140.

[20] Trivedi MK, Patil S, Shettigar H, Gangwar M, Jana S (2015) In vitro evaluation of biofield treatment on cancer biomarkers involved in endometrial and prostate cancer cell lines. J Cancer Sci Ther 7: 253-257.

[21] Trivedi MK, Branton A, Trivedi D, Nayak G, Shettigar H, Mondal SC, Jana S (2015) Effect of biofield energy treatment on Streptococcus group B: A postpartum pathogen. J Microb Biochem Technol 7: 269-273.

[22] Trivedi MK, Branton A, Trivedi D, Nayak G, Bairwa K, Jana $\mathrm{S}$ (2015) In vitro evaluation of antifungal sensitivity assay of biofield energy treated fungi. Fungal Genom Biol 5: 125.

[23] Trivedi MK, Branton A, Trivedi D, Nayak G, Mondal SC, Jana S (2015) Evaluation of plant growth, yield and yield attributes of biofield energy treated mustard (Brassica juncea) and chick pea (Cicer arietinum) seeds. Agriculture, Forestry and Fisheries 4: 291-295.

[24] Trivedi MK, Branton A, Trivedi D, Nayak G, Gangwar M, Jana S (2015) Effect of biofield energy treatment on chlorophyll content, pathological study, and molecular analysis of cashew plant (Anacardium occidentale L.). Journal of Plant Sciences 3: 372-382.

[25] Trivedi MK, Branton A, Trivedi D, Nayak G, Mishra RK, Jana S (2015) Physicochemical evaluation of biofield treated peptone and malmgren modified terrestrial orchid medium. American Journal of Bioscience and Bioengineering 3: 169-177.

[26] Trivedi MK, Branton A, Trivedi D, Nayak G, Singh R, Jana S (2015) Physicochemical characterization of biofield treated orchid maintenance/replate medium. Journal of Plant Sciences. 3: 285-293.

[27] Trivedi MK, Patil S, Tallapragada RM (2013) Effect of biofield treatment on the physical and thermal characteristics of silicon, tin and lead powders. J Material Sci Eng 2: 1-7.

[28] Trivedi MK, Nayak G, Patil S, Tallapragada RM, Latiyal O, Jana S (2015) Evaluation of biofield treatment on physical and structural properties of bronze powder. Adv Automob Eng 4: 119.

[29] Trivedi MK, Branton A, Trivedi D, Nayak G, Bairwa K, Jana S (2015) Spectroscopic characterization of disulfiram and nicotinic acid after biofield treatment. J Anal Bioanal Tech 6: 265.

[30] Trivedi MK, Patil S, Shettigar H, Singh R, Jana S (2015) An impact of biofield treatment on spectroscopic characterization of pharmaceutical compounds. Mod Chem Appl 3: 159.

[31] Trivedi MK, Tallapragada RM, Branton A, Trivedi D, Nayak G, Latiyal O, Mishra RK, Jana S (2015) Physicochemical characterization of biofield energy treated calcium carbonate powder. American Journal of Health Research 3: 368-375.

[32] Trivedi MK, Nayak G, Patil S, Tallapragada RM, Jana S, Mishra RK (2015) Bio-field treatment: An effective strategy to improve the quality of beef extract and meat infusion powder. J Nutr Food Sci 5: 389.

[33] Trivedi MK, Branton A, Trivedi D, Nayak G, Saikia G, Jana S (2015) Thermal, spectroscopic and chromatographic characterization of biofield energy treated benzophenone. Science Journal of Analytical Chemistry 3: 109-114.

[34] Trivedi MK, Patil S, Mishra RK, Jana S (2015) Structural and physical properties of biofield treated thymol and menthol. J Mol Pharm Org Process Res 3: 127.

[35] Trivedi MK, Tallapragada RM, Branton A, Trivedi D, Nayak G, Mishra RK, Jana S (2015) Characterization of physical, spectroscopic and thermal properties of biofield treated biphenyl. American Journal of Chemical Engineering. 3: 5865 .

[36] Trivedi MK, Branton A, Trivedi D, Nayak G, Saikia G, Jana S (2016) Determination of isotopic abundance of ${ }^{2} \mathrm{H},{ }^{13} \mathrm{C},{ }^{18} \mathrm{O}$, and ${ }^{37} \mathrm{Cl}$ in biofield energy treated dichlorophenol isomers. Science Journal of Analytical Chemistry 4: 1-6.

[37] Trivedi MK, Branton A, Trivedi D, Nayak G, Sethi KK, Jana S (2016) Gas chromatography-mass spectrometry based isotopic abundance ratio analysis of biofield energy treated methyl-2-napthylether (Nerolin), American Journal of Physical Chemistry 5: 80-86.

[38] Trivedi MK, Branton A, Trivedi D, Nayak G, Panda P, Jana S (2016) Gas chromatography-mass spectrometric analysis of isotopic abundance of ${ }^{13} \mathrm{C},{ }^{2} \mathrm{H}$, and ${ }^{18} \mathrm{O}$ in biofield energy treated $p$-tertiary butylphenol (PTBP). American Journal of Chemical Engineering 4: 78-86.

[39] Trivedi MK, Branton A, Trivedi D, Nayak G, Panda P, Jana S (2016) Isotopic abundance ratio analysis of 1,2,3trimethoxybenzene (TMB) after biofield energy treatment (The Trivedi Effect ${ }^{\circledR}$ ) using gas chromatography-mass spectrometry, American Journal of Applied Chemistry 4: 132140.

[40] Schellekens RC, Stellaard F, Woerdenbag HJ, Frijlink HW, Kosterink JG (2011) Applications of stable isotopes in clinical pharmacology. Br J Clin Pharmacol 72: 879-897.

[41] Muccio Z, Jackson GP (2009) Isotope ratio mass spectrometry. Analyst 134: 213-222.

[42] Vanhaecke F, Kyser K (2012) Isotopic composition of the elements In Isotopic Analysis: Fundamentals and applications using ICP-MS (1stedn), Edited by Vanhaecke F, Degryse P. Wiley-VCH GmbH \& Co. KGaA, Weinheim. 
[43] Smith RM (2004) Understanding Mass Spectra: A Basic Approach, Second Edition, John Wiley \& Sons, Inc, ISBN 0471-42949-X

[44] Meija J, Coplen TB, Berglund M, Brand WA, De Bievre P, Groning $\mathrm{M}$, Holden NE, Irrgeher J, Loss RD, Walczyk T, Prohaska T (2016) Isotopic compositions of the elements 2013 (IUPAC technical Report). Pure Appl Chem 88: 293-306.

[45] Asperger S (2003) Chemical Kinetics and Inorganic Reaction Mechanisms Springer science + Business media, New York.
[46] Trivedi MK, Mohan TRR (2016) Biofield energy signals, energy transmission and neutrinos. American Journal of Modern Physics 5: 172-176.

[47] Cleland WW (2003) The use of isotope effects to determine enzyme mechanisms. J Biol Chem 278: 51975-51984.

[48] Nikolic VD, Illic DP, Nikolic LB, Stanojevic LP, Cakic MD, Tacic AD, Ilic-Stojanovic SS (2014) The synthesis and characterization of iron (II) gluconate. Advanced technologies 3: $16-24$. 